\title{
关于水利工程施工安全管理的思考
}

\author{
楼易承 靳永卫 吴小林 李吴晏 姜羽寒 \\ 浙江缙云抽水蓄能有限公司 \\ DOI:10.32629/hwr.v3i11.2476
}

[ 摘 要] 水利工程作为我国基础的民生工程项目,其建设对于我国经济社会发展都有重要影响,而且水利工程在应用的过程中,不仅仅能够发挥 其本身的社会效益,还能创造出经济效益,所以对水利工程进行施工和管理就至关重要。水利工程由于其规模十分巨大,所以在施工时任何一个 施工流程或施工环节出现了偏差, 都会影响其最终的施工质量, 也会造成施工安全隐患, 造成不必要的损失。因此在水利工程施工过程中,要求必 须要加强施工安全管理工作,保证水利工程项目的顺利施工。

[关键词] 水利工程; 工程施工; 安全管理; 措施

\section{1 水利工程施工的特点}

1. 1水利工程的作用就是起到挡水、蓄水和泄水等作用, 因此对于建造 水利建筑物的要求就比较严格, 不能用建造普通建筑物的方法, 水利工程 必须要具备稳定承压、防渗抗冲、耐磨、抗冻抗裂等特殊要求, 这就要求 水利施工企业必须按照水利工程的技术要求, 使用专门的施工方法和措施 来保障水利工程建设。

1. 2 水利工程对建造处地基的要求也较为苛刻, 水利工程的选址经常 是在地形比较复杂和偏僻的地方, 这就对施工的难度有所增加, 如果前期 地基处理不好, 或者是安全技术水平不足, 则会造成很大的安全隐患, 而一 旦发生意外, 就会造成高额的经济损失, 和人员伤亡。

1.3 水利工程很多时候都是建造在水流附近, 地形崎岖, 不易建造, 这 就需要同时考虑水流带来的影响和安全施工的要求, 必须同时满足这两个 要求, 才能完成水利工程的建设, 二者忽略一个, 都会留下隐患, 对以后工 程的使用造成危害。

1.4 水利工程多建造在水流、河流附近, 水流湍急, 不容易建设, 这对于 施工期就有了一定的季节性要求, 要充分利用枯水期来建设水利工程, 这 就在施工工程期上具有硬性要求, 必须要提前做好准备工序, 利用好枯水 期的间隙, 确保工程如期开展。

\section{2 水利工程施工安全管理的重要性}

2.1 与生命生产有关。在水利工程建设中, 安全有利于企业和社会的发 展。如果经常出现安全问题, 会影响日常生活和生产质量。在水利工程建设 不安全的情况下, 工程设施的质量会有一定程度的下降, 危及工程所涉及地 区的人民群众的安全和生产活动。与其他建设项目相比, 水利设施的管理和 控制难度较大, 造成的财产损失和安全问题更为严重。目前, 一些企业在水 利工程建设中, 其安全管理工作不到位, 将对企业和社会造成严重影响。

2.2 与政府形象有关。从宏观上看, 水利工程属于国家工程, 但在微观 层面上属于市政工程。因此, 如果施工过程中出现安全和质量问题, 就会破 坏政府形象, 影响人民群众的威信。作为水利建设的管理部门和监督部门, 对政府的有效管理和监督不仅关系到建设的安全, 而且关系到政府形象的 建设。由于水利工程的需要, 建设周期长, 与施工单位进行分包由不同的企 业和施工单位, 如果安全问题出现在建设, 这将会对参与施工的企业形象 直接影响, 甚至会影响到企业后续发展。

\section{3 水利工程施工安全管理存在的问题}

3. 1 没有足够重视安全管理。近年来, 我国水利行业处于快速发展阶段, 在这一背景下, 许多建设单位只追求速度, 希望用较少的时间完成各项建 设任务。许多施工单位在施工中只注重质量管理, 安全管理不足, 由于安全 管理的落实不到位, 在施工过程中存在着许多安全问题, 这些问题将逐渐
出现在实际施工过程中, 影响到水利工程的整体安全。

3.2 安全管理意识淡。目前, 许多水利工程施工人员素质普遍不高, 施 工中缺乏安全意识, 使得水利工程施工安全工作实施不到位, 影响了水利 工程的安全。施工单位缺乏岗前培训制度, 缺乏对安全的积极宣传, 导致许 多未经培训的人员直接上岗, 导致可能安全事故的发生。

3. 3管理制度不全。现在许多单位还没有建立有效的管理机制, 在管理 机制建设中存在许多问题。在水利工程建设中, 许多单位没有充分发挥自 身的管理效能, 导致施工现场安全管理水平不高, 水利工程的施工没有按 规范进行施工管理, 造成水利工程的许多不规范现象, 这给工程埋下了巨 大的隐患。

\section{4 水利工程施工安全管理加强建议}

在水利企业长远发展中加强水利工程施工安全管理十分重要, 其是确保 水利工程整体质量的基础, 也是提出水利工程经济效益的关键。为此, 相关人 员需给予水利工程施工安全管理高度重视, 加强水利工程施工安全管理。

4.1 强化制度建设与管理。若想对水利工程施工进行有效规范, 保证施 工有序开展, 需构建相对完善的施工制度来监督水利工程施工状况。而为 了保证水利工程施工安全, 则需构建有关的施工标准与安全机制, 对作业 人员的作业行为与管理人员的管理行为进行有效约束, 进而保证水利工程 施工的标准化与系统化。为了深入加强水利工程施工安全管理, 需针对安 全机制构建有关监督流程, 增强对制度实行状况的监管, 进而保证安全管 理机制能够依法落实。在水利项目施工中, 有较强危险性的施工环节, 需严 格依照有关管理与规定开展施工, 并严密监管水利工程施工过程。

4.2 严格项目法人管理。项目法人在工程开工前, 要在质量监督机构办 理质量监督手续。建立健全工程质量管理体系, 依法择优选择勘察、设计、 施工、监理、质量检测等单位和人员, 签订的合同文件中应对工程质量以 及相应的责任和义务作出明确规定。要强化对参建单位现场机构设置和合 同人员到位、履职、出勤情况的监督管理, 除不可抗力因素外, 严禁承建单 位随意变更、调整、减少合同人员, 严格按照不低于合同资质、能力、业 绩的条件、标准审核合同人员变更, 严格对有关单位的质量行为、质量过 程和实体工程质量进行监督。

4.3 严格勘察设计管理。勘察、设计单位要建立健全勘察、设计质量 保证体系, 认真贯彻执行有关法律、法规和技术标准, 加强勘察、设计全过 程的质量控制。勘察单位提供的地质、测量、水文等勘察成果必须真实可 靠。设计单位提交的设计文件要符合国家和行业规定的设计深度要求, 设 计单位在设计文件中选用的材料、中间产品和设备, 必须符合国家规定的 标准, 并注明规格、性能、型号等技术指标。要加强工程现场服务, 大中型 水利工程必须设置现场设计代表机构, 小型水利工程应配备满足工作需要 


\section{现代化技术应用到河道堤防工程的管理及维护分析}

徐帷巍

雃州市信安湖管理处

DOI:10.32629/hwr.v3i11.2513

[ 摘 要] 河道堤防工程是水利工程的重要组成内容,其关系到整个水利工程的质量与水利工程的基础功能能否实现,但从当前水利工程施工建 设中, 由于河道堤防工程管理以及维护始终得不到重视, 导致河道堤防工程的作用与功能无法发挥, 影响着水利工程运行的稳定性与安全性。为 此,随着科学技术的发展,基于现代化技术展开河道堤防工程的管理与维护能够有效提升管理与维护工作的质量与效果。基于此,文章具体探究 了现代化技术应用到河道堤防工程管理与维护中的策略。

[关键词] 现代化技术; 河道堤防工程; 管理; 维护

经济的快速发展, 社会对水利工程的防洪功能也提出了更高的要求, 但是由于当前河道堤防工程的管理与维护存在问题, 导致水利工程的防洪 功能在一定程度上被减弱, 这种情况严重影响着水利工程建设的效益与发 展。因此, 基于当前河道堤防工程的管理与维护现状, 利用先进的技术手段, 提升管理与维护工作水平, 实现河道堤防工程健康、安全、稳定运营, 对于 水利工程整体功能与效益的实现有着重要的现实意义。

\section{1 河道堤防工程的管理与维护现状}

一是, 河道堤防工程管理理念落后, 水利工程作为我国基础设施的重 要部分, 其关系到社会的和谐稳定发展与经济建设, 其是一项经济效益、社 会效益、生态效益兼具的工程项目, 完善的管理制度对提升其效益有着重 要的帮助。但是由于水利工程运维管理环境艰苦、工作复杂, 相关专业人 才短缺。而河道堤防工程作为水利工程的重要组成部分, 其管理与维护工 作仍然处于落后状态, 因整个水利工程的管理与维护工作没有完善的制度 做保障, 河道堤防工程始终得不到运维管理部门的重视, 从而导致当前河 道堤防工程运营过程中频繁出现问题 ${ }^{[1]}$ 。

二是, 河道淤泥与河床上升问题严重。随着社会的发展, 城市化、工业 化进程的加快, 日常生产、生活活动对生态环境与自然环境造成了极为严 重的破坏, 导致我国水土流失问题逐年加剧, 从而导致和道长后尾边坡绿

的设计代表, 及时解决设计问题。

4. 4加大施工现场安全管理力度。针对水利工程安全管理现状来讲, 施工场地的安全管理工作为其中十分关键的内容, 同安全管理效果有直接 关联。为此, 施工单位需加大对施工场地安全管理力度, 并把安全管理工作 依据管理者的职能需求, 落到实处, 进而把握住安全管理工作的实效性。同 时, 需构建独立的监管机构对施工场地的安全管理工作进行动态监督, 进 而将安全隐患消除掉, 保证施工人员与现场安全, 进而推动水利工程施工 稳定进行。

4. 5 加强安全生产教育力度。为了推动水利工程有序开展, 需给予安全 施工现场完全管理高度重视。为此, 针对水利施工过程中的安全问题, 作业 人员与有关管理者需增强对作业部门的安全管理教育, 以保证作业人员安 全施工, 进而加强他们的完全意识。为了推动水利施工企业给予安全生产高 度重视, 我国水利部门需构建有关安全的生产机制, 以监督与督促施工单位 的安全管理工作。另外, 施工企业需严格依据国家构建的安全生产机制开展 生产作业, 并布设有关奖惩制度来调动作业人员安全作业的主观能动性。

4. 6 落实从业人员责任。勘察设计人员对其签字的设计文件负责。施 工单位项目经理、技术负责人和质量管理责任人按照各自职责对实体工程 质量和签字确认的质量检验评定结论负责。总监理工程师、监理工程师按
化退化、植被无法正常生长, 从而出现了河道淤积情况, 迫使河床出现上 升。此外, 随着我国水利工程建设规模的扩大, 很多地区为了方便生产活动, 将城市垃圾、工业垃圾、农业垃圾等大量物质倾倒在河道, 这也是导致河 道淤泥的主要因素。而目前由于河道堤防工程管理与维护工作始终得不到 重视, 河道淤积以及河床上升问题始终得不到有效的解决, 容易导致水利 工程丧失防洪功能, 从而在雨季威胁民众的安全。

三是, 管理与维护人员能力与素质问题, 大部分水利工程到建设在人 迹罕至的野外, 而对工程的管理与维护需要工作人员长时间驻扎在施工现 场, 实现全方位的管控, 但艰苦的环境与工作条件导致很多专业管理人员并 不愿从事该行业, 从而专业管理人员与维护人员贵乏问题十分突出 ${ }^{[2]}$ 。这就 导致很多素质与专业技能不达标的工作人员涌入了行业内部, 其不能根据 施工现场工程的运行情况做出正确的判断与决策, 从而导致管理与维护工 作水平始终无法提升。

\section{2 河道堤防工程管理与维护的现实意义}

对河道堤防工程的管理与维护使其能够有效发挥出抵御重大洪港 灾害的作用。洪涝灾害是我国雨季汛期频繁发生的大型地质性灾害, 其 会对民众的生命财产健康带来严重的威胁, 而水利工程的建设目标中也 明确指出其具有防洪抗涝的功能, 而这项功能的实现主要依靠河道堤防

各自职责对监理工作负责, 对签字确认的验工计价表和质量验收评定结论 负责。质量检测、工程监测、鉴定评估等从业人员按照各自职责对检测、 监测、鉴定评估的原材料、中间产品和结论负责。建立质量控制关键岗位 责任制, 强化对关键岗位持证上岗情况的监督检查, 严格按照质量规范操 作。造成质量事故的, 要依法追究有关从业人员的责任。

\section{5 结语}

为了保证人们生活质量及国家经济的稳定发展, 必须保证水利工程的 质量及安全。由于水利工程施工涉及的专项技术较多, 工期较长, 施工规模 较大且施工环境复杂等特点, 使得水利工程施工的安全管理工作难度加 大。施工企业应采取有效措施, 积配合政府有关部门的监督管理, 落实安全 生产工作, 保证水利工程施工的安全顺利进行, 提高工程质量。

\section{[参考文献]}

[1]杨伟.水利工程施工的现场管理关键探索[J].智能城市,2019(19):97-98. [2]卢乾.水利工程施工质量与安全管理措施探析[J].科技风,2019(26): 197.

[3]周冬梅.水利工程施工中的安全管理措施探析 [J]. 现代物业 (中旬 刊),2018(10):229.

[4]张峰.水利工程施工中的质量控制与安全隐患管理[J].建材与装 饰,2019(26):295-296. 